\title{
IMPACT OF THE COVID-19 PANDEMIC ON LOGISTICS FIRMS AND THEIR RESILIENCE: CASE STUDIES IN THAILAND
}

\author{
SUn Ketudat ${ }^{\circledR}$ Chawalit JeEnanunta
}

\begin{abstract}
A B S T R A C T
The novel Coronavirus (COVID-19) is an infectious disease that is currently causing challenges and opportunities in all sectors worldwide. The logistic industry plays an enormous role in keeping the countries functional, and it accounts for $13.4 \%$ of the total GDP in Thailand. This article aims to identify and justify critical success factors for the Logistic Industries experiencing success and failure during the pandemic. The research was conducted using semi-structured interviews with top managers of three companies from March to September 2021, which is phase 4 of the pandemic. The findings we analysed using thematic analysis to understand the critical factors within the industry. Logistics companies of different sizes were selected for this purpose as case studies aimed to identify the resemblance of the effects and find the relationship with company resilience. Five key supporting factors were identified for the logistics firms to be resilient during the pandemic, including flexibility, Business Continuity Plan, market diversification, IT systems, and leadership.
\end{abstract}

KEY WORDS

COVID-19, logistics industry, business continuity plan, thematic analysis, Thailand, resilient, cross-comparison

10.2478/emj-2021-0023
Chawalit Jeenanunta

Thammasat University, Thailand ORCID 0000-0002-1932-9776

Corresponding author: e-mail: chawalit@siit.tu.ac.th

Sun Ketudat

Thammasat University, Thailand ORCID 0000-0002-1563-4845

\section{INTRODUCTION}

The novel Coronavirus (COVID-19) is an infectious disease currently terrorising the world. It was first officially reported in the City of Wuhan, China, in December 2019. The pandemic affected everyone, leading to a crisis in all industries around the globe. Businesses are forced to adapt and adjust to the "new normal" to survive in the new world with the COVID19. From January 2020 to September 2021, Thailand had approx. 1200000 confirmed cases of COVID-19,

Ketudat, S., \& Jeenanunta, Ch. (2021). Impact of the COVID-19 pandemic on logistics firms and their resilience: case studies in Thailand. Engineering Management in Production and Services, 13(3), 86-98. doi: 10.2478/emj-2021-0023 
with roughly around 12000 deaths. The number of infections has increased throughout each phase, with the highest number of 22000 new cases on a single day. Thailand had implemented a lockdown policy for the population's safety to decrease or prevent the spread of the infection.

To understand resilience under the COVID-19 pandemic, challenges faced by industries must be identified and analysed in terms of time and the scope of influence, resulting in business interruptions and bottlenecks. Extreme uncertainty can be caused, e.g., by political instability, pandemic, terrorism, natural disasters, and a financial meltdown. Challenges differ by scope and duration; thus, resilience scenarios also vary depending on challenges. Another aspect for consideration is the internal business and industry challenges faced by managers, such as increased workload, the second shift in the form of domestic work and home-schooling, employee loyalty in the home office, extended availability outside working hours, tight timing and high density as well as content-rich online meetings, and widespread changes. Business resilience is achieved by preparing for strange events. Coping with the pandemic requires prevention and protection, adaptability and reactivity to challenges, and the ability to recover with greater strength after the pandemic.

This paper analyses the effects caused by the COVID-19 pandemic on the logistics industry in Thailand to identify positive and negative aspects and understand the resilience of companies operating in the field. The data was collected from three different logistics companies. The study was conducted using a semi-structured interview and thematic analysis (Braun \& Clarke, 2006) to derive a theme for the resilience key factors (Scharte et al., 2014). The three selected companies represent the logistics industry in Thailand. Respondents represented the top management of the companies. The research paper aspired to find the overall effect throughout the four pandemic phases from the beginning of 2020 up to September 2021.

In addition to the effect of the COVID-19 pandemic, the paper also focused on the "new normal", i.e., the lifestyle policies implemented on-site and off-site in each company. The first COVID-19 case in Thailand was reported in January 2020. The number of cases drastically increased in the first phase between March to May 2020 due to the lack of awareness of the new virus. As a result, the government was forced to act and implement a lockdown policy, closing schools, nightclubs, and other public places.
Closed airports and travel restrictions made employees switch to working from home. Additionally, the government placed a curfew for 22.00-04.00 hrs. As the number of infections decreased, the government lifted the lockdown regulation. Thailand's citizens experienced too much stress due to working from home or unemployment. Phase 2 started in January to March 2021; the number of infections surged as a new cluster emerged from the Myanmar labour in Samut Sakhon. The government returned to the restriction policies forbidding migrant workers to travel to provinces with high infection levels in Samut Sakhon, Chonburi, Rayong, Chantaburi, and Trad. Phase 3 began in April 2021 with an infection cluster from clubs in Thonglor, resulting in the return to the lockdown policies. Furthermore, phase 4 and the most recent lockdown started in July, with COVID19 spreading throughout all provinces.

\section{LITERATURE REVIEW}

Researchers have investigated the impact of the pandemic and business resilience in other industries using various organisational concepts. E.g., delivery and takeaway services have a strong positive effect on the business resilience of the restaurant and bar industry (Neise et al., 2021). The COVID-19 impact is significant for the airline industry, which saw a massive drop in stocks and the market. Possible policies are suggested to help industries cope with the pandemic and recover after the crisis (Maneenop \& Kotcharin, 2020).

Businesses that implemented a well-prepared Business Continuity Plan as a strategic management counter to the COVID-19 pandemic are likely to be more efficient in terms of survivability and recovery (Margherita \& Heikkilä, 2021).

Resilience is the ability of businesses to quickly respond, react, and adapt to a downfall. Businesses that overcome a downfall make improvements related to internal and external factors. Different factors contribute to the resilience during the pandemic, such as the workforce, social, environmental, operational, commercial, financial aspects and future resilience. Examples of internal factors are the workforce, operational and financial aspects, and future resilience. Workforce resilience plays a massive role as an internal factor; thus, protective and preventive measures are crucial during the pandemic. Staff is a vital business asset in managing the workflow. Operational and future resilience are internal factors 
that impact continuous value generation and require to implement risk management and operational plans during the pandemic and later. Financial resilience is an internal factor related to the management of cash flows and the business value to identify possible performance improvements and loss cuts. Social, environmental, and commercial resilience are examples of external factors (Al-Ayed, 2019). Social and environmental resilience can influence the business positively. The resilience cycle consists of preparation, prevention, protection, response, and recovery (Scharte et al., 2014). Shin and Park found that leadership is a significant factor in the firm's resilience during disruptive events (Shin \& Park, 2021). Wang and Chen found that diversification and flexibility enhance the firm's efficiency (Wang \& Chen, 2021).

\section{RESEARCH METHODS}

The research was qualitative and used semistructured interviews for thematic analysis as a deductive approach. The aim was to identify the pandemic effects on the logistics companies in Thailand. The semi-structured questions were formulated by the authors. The thematic analysis was applied, using six steps: familiarise the data set, initial codes, generate codes, validity and reliability of the themes, define and name the themes, and interpret and report.

This research aimed to find positive and negative effects faced by the logistics industry in Thailand during the 4 phases of the COVID-19 pandemic. The semi-structured interview asked questions regarding the company's background, the status before and during the 4 phases of the COVID-19 pandemic, and the

Tab. 1. Characteristics of case studies

\begin{tabular}{|c|c|c|c|}
\hline COMPANY CHARACTERISTICS & CASE A & CASE B & CASE C \\
\hline Established & 2018 & 1988 & 1989 \\
\hline Size & Small & Midsize & Large \\
\hline Number of staff & 15 & $\begin{array}{l}92 \text { in Thailand } \\
280+\text { (Total) }\end{array}$ & $\begin{array}{l}\text { 700+staff in Thailand } \\
\text { 100+ outsource } \\
22,000+\text { staff (Total) }\end{array}$ \\
\hline Number of offices & 1 & $\begin{array}{c}6 \text { in Thailand } \\
80 \text { partners globally }\end{array}$ & 500 \\
\hline Covered region & Global & $\begin{array}{l}\text { Global, but focuses mainly on } \\
\text { South-East Asia }\end{array}$ & Global \\
\hline Focused Region & International Market & Local Market & International Market \\
\hline Services provided & $\begin{array}{l}\text { sea } \& \text { air freight, customs } \\
\text { clearance, warehousing and } \\
\text { distribution services etc. }\end{array}$ & $\begin{array}{l}\text { sea \& air freight, truck inland } \\
\text { transportation, customs clear- } \\
\text { ance, warehousing and distri- } \\
\text { bution services etc. }\end{array}$ & $\begin{array}{l}\text { total supply chain solution } \\
\text { freight \& logistic services (air, } \\
\text { sea, road, warehousing } \\
\& \text { distribution, supply chain } \\
\text { solutions, systems \& technolo- } \\
\text { gies), industry solutions (auto- } \\
\text { motive, chemicals, consumer } \\
\text { goods, defence \& government, } \\
\text { energy \& petrochemicals etc.) }\end{array}$ \\
\hline $\begin{array}{l}\text { Specialised product of trans- } \\
\text { portation }\end{array}$ & $\begin{array}{l}\text { Specialises in food, food pack- } \\
\text { aging (dry \& frozen), automo- } \\
\text { tive, \& medical equipment }\end{array}$ & $\begin{array}{l}\text { Specialises in general cargo } \\
\text { (automobile-parts, machinery, } \\
\text { home \& furniture, canned } \\
\text { food, tech gadgets, etc.), per- } \\
\text { ishable (Thai agricultural prod- } \\
\text { ucts - seasonal fruits), project } \\
\text { cargo (oversized cargo both air } \\
\& \text { sea) }\end{array}$ & $\begin{array}{l}\text { Specialises in transporting; } \\
\text { high-tech electronics, indus- } \\
\text { trial, and life-science products } \\
\text { (pharmaceutical) }\end{array}$ \\
\hline
\end{tabular}


response to the pandemic, such as the actions taken, risk management, and Business Continuity Plans.

The research participants were top managers of three different logistics companies of different sizes, which were selected hoping to find the resemblance and patterns of the COVID-19 effects.

\section{RESEARCH RESULTS}

The selected companies were used as a case study to show challenges, opportunities, and the main overall effect within each phase of the COVID-19 pandemic. For Case A, B, and C, the participants of the semi-structured interview held positions of Managing Director, Business Development Executive, and Managing Director, respectively. The characteristics of the participants are summarised in Table 1 . The research provided a sufficient amount of data for thematic analysis and finding the key resilience factors during the pandemic.

\subsection{CASE A}

Case A is a new logistics company established in 2018 with more than 15 staff members. Covering logistics globally, it specialises in the transport of goods between Thailand and the United States, targeting international markets. The company specialises in the transport of food, food packaging for dry and frozen products, automotive and medical equipment, and some other niche goods.

The company provides sea and air freight services. Approx. $65 \%$ of its business is sea freight, and the rest - air freight. Other services include the customs clearance, warehousing, and distribution. The company owns only one office, which is the headquarters located in the central district of Ekamai. It is known as a small logistics company acting as a freight forwarder, arranging shipments from suppliers to customers for individuals and corporations. A freight forwarder acts as an agent contacting other logistics providers to carry out shipments using different modes of transport via sea, air, rail, and land.

The company faced several challenges during the pandemic. Many people could not get to work. Employees and customers of the company had to work from home, which meant they lacked the usual access to their resources, causing delays and cancellations in production. The company was affected by the loss of continuous orders that were expected before the COVID-19 pandemic.
Nevertheless, some opportunities were created as well. Due to the lockdown, which was especially noted in the UK, people experienced boredom and tiredness, which resulted in the use of e-commerce. A surge was registered in the demand for products from Asia and especially Thailand.

From October 2020, in the hype of the COVID19 pandemic, the demand was so high that shipping line vessels for cargo transportation were overwhelmed and fully booked. However, a crisis was expected in July 2020. Shipping companies panicked and pulled large vessels out, aiming to cut predicted losses. However, the surged demand skyrocketed cargo prices. The sudden lack of equipment and space provided the logistics industries with an enormous opportunity, and the price has increased 10 -fold since October 2020.

With people spending more and limited capacity and space, company A substantially advanced in the logistics industry. As the company had space allocation and supply contracts, a sudden massive booking of shipments came through. The available capacity helped the company make a massive income.

New customers from different countries and industries became interested in the company for supply for logistics services. For a small company with limited competitive power, things have turned around. It stumbled upon opportunities that were never available before.

To respond to the COVID-19 pandemic, the company implemented risk management measures, such as telecommunications for conducting businesses, social distancing, working from home, wearing masks, regular use of alcohol gel and spray, and temperature checks before and after work. The company plans to expand, using the opportunities given by the pandemic.

\subsection{CASE B}

Case B is a mid-size company established in 1988, with 92 staff members, six offices worldwide, and the headquarter located in the Bangna district, which is a suburban area of Bangkok City. The company provides logistics services worldwide but focuses more on Southeast Asia with over 80 partners globally. Company B is a freight forwarder that offers a one-stop-shop service for multimodal logistics, sea and air freight, truck-inland and cross-border transportation, customs clearance and consultancy, warehousing and distribution services, special projects and site logistics. The company specialises in the 
logistics of general cargo, perishable products, and project cargo management. The general cargo consists of automobile parts, machinery, home and furniture, canned food, tech gadgets etc. Perishable products are mostly Thai agricultural produce (e.g., seasonal fruits), and project cargo management relates to the transportation of oversized cargo via air and sea.

Before the COVID-19 situation, the company experienced an increase in the transportation of e-commerce products (i.e., tech gadgets) and tried to obtain new accounts as more SMEs imported products from China and other countries. Some opportunities were created before the pandemic as the Thai government invested more in the infrastructure, which attracted more investments, such as the EEC project and more free trade agreements. However, the attempt to acquire new accounts faced difficulties due to pricing and competition.

As a result of the COVID-19 pandemic, imports and exports remained the same as before the pandemic. However, the total volume of imports and exports has decreased significantly. An increase was registered in the volume of food and medical products; however, a decrease was experienced in the volume of clothing and home decoration products.

The company faced similar challenges as in the previous case, i.e., employees having to work from home, cancelled orders and production, dropped orders from regular contractors, more prolonged bottlenecks within the delivery process, difficulties in booking and getting space, and container imbalance for customers, which may result in a loss of customers. Opportunities were created in the form of growing e-commerce shipments due to the rise of online platforms globally. Since there was a shortage of containers, new export and import companies became interested in company B for space and bookings.

In response to the pandemic, company $\mathrm{B}$ implemented safety procedures for staff, asking $50 \%$ of them to work from home and others to come into the office once every week or two. Also, customer visits were limited to only those inevitable and, upon advance permission, refraining as much as possible from outside visitors. Transportation services were provided for staff members to be dropped off and picked up from their houses to their workplaces. The company moved their counter services to a warehouse for releasing the Bill of Lading $(\mathrm{B} / \mathrm{L})$ and Delivery Order $(\mathrm{D} / \mathrm{O})$. The staff was requested to wear masks and regularly use alcohol gel. Employees having a temperature higher than $37.5^{\circ} \mathrm{C}$ were trans- ferred to the hospital, staff members were asked to wear masks in public places, all business trips were deferred until further notice, and private employee trips or annual leaves were to be agreed upon in advance with the management. Also, offices were regularly deep cleaned and disinfected. For company $B$, the overall effect was mostly negative, but the business is slowly recovering.

\subsection{CASE C}

Company C was established in 1989 and is considered a large global logistics business. It provides a total supply chain solution and has more competitive power compared to other players in the logistics industry. Company $\mathrm{C}$ has been acquired and taken over many times over the years. It has over 700 regular staff members in Thailand and more than 100 outsourced. In total, it has over 22000 staff members and more than 500 offices worldwide. The company provides a total supply chain solution of freight and logistics services, such as transportation via air, sea and land, warehousing and distribution, supply chain solutions, and systems and technologies. The company also offers industry solutions in the automotive, chemicals, consumer goods, defence and government, energy and petrochemicals sectors etc. Company $\mathrm{C}$ focuses on international trade and transport of specialised goods, such as high-tech electronics (82 $\%)$, industrial (12\%) and life-sciences products (5\%), such as pharmaceuticals and other (1\%).

Freight is primarily transported via air and sea. The rail network is underdeveloped in Thailand. The country had plans to connect the railway system to Laos and China, but they had to be postponed due to the COVID-19 pandemic.

Before the pandemic, airlines prioritised their services for passengers, which roughly amounted to $70-80 \%$ of their business, with the rest representing cargo and other services.

In terms of air freight in 2019, Thailand focused on export, which roughly amounted to 1400000 tons and the annual revenue of THB $3000-4000$ million. In April 2020, the airline stopped operating due to the COVID-19 pandemic, which caused a vast disruption in transportation. The volume dropped by $35 \%$ by the end of 2020. Airfreight exported 900000 tons and doubled the revenue to THB 7000 million.

During the national lockdown, the airline was forced to temporarily shut down. This posed a massive challenge for logistics companies offering air freight as airlines had to cancel flights for passengers. 
In over 30 years of experience as the managing director, this was the first time when flights only carried cargo and no passengers. The pandemic caused some technical difficulties with the weight balance since aircrafts had cargo underneath and no passengers. This issue had to be resolved.

Usually, a wide-body or large aircraft can hold roughly an average of 200 passengers of $100 \mathrm{~kg}$ per person, which is equivalent to 20 tons. In addition, it can hold up to 5 - 30 tons of cargo. A narrow-body or small aircraft has a maximum weight limit of 1 or 2 tons. Once the technical difficulty with the weight imbalance was resolved, a wide-body aircraft held up to $50-56$ tons. The cost for logistics using air freight has been very high.

Company $\mathrm{C}$ has faced more challenges compared to the previous two cases due to its size and more direct challenges caused by the pandemic, namely, putting air freight on hold, weight balancing, and decreased volumes. Other challenges were related to employees working from home, cancellation of orders, a more prolonged bottleneck at the delivery process, the shortage of labour and cargo. Some staff members stopped working due to the fear of getting infected.

On the other hand, the company experienced an enormous benefit from the COVID-19 pandemic. Due to a significant increase in e-commerce and sudden shortages, the company saw a $200-400 \%$ increase in revenue. Air-charters were more frequent, customers used different freight services, and the willingness-topay increased. The company had the competitive power to set the price for the customers.

The volume of imported and exported products decreased because of the panic among the on-site and the off-site workers, fearing the pandemic. This resulted in a sudden labour shortage. On the other hand, the company's revenues spiked up from the sudden shortage of services and a surge in demand, causing the prices to increase drastically. The willingness-to-pay increased because of the need to transport fresh products and the high customer demand.

To ensure risk management, the company had a Business Continuity Plan for such situations as the pandemic. The plan aimed to keep the workflow continuous. Aiming to ensure safety, on-site and off-site staff were given laptops with private VPNs to conduct work from home. On-site employees operated in shifts as Team A and Team B, rotating once every week to ensure appropriate social distancing. Also, the company rented a VPN server for conducting business from home. All staff members had to wear masks, observe social distancing, use alcohol disinfectant, wash hands etc. Also, infected members of staff had to stay in isolation and follow a set of rules set out in the BCP. Telecommunication for business meetings and online learning for new staff members were used as well.

Looking at all four phases of the COVID-19 pandemic, phase one (beginning of 2020) posed a challenge in terms of decreased volume. Phase two (the second half of 2020) saw a slow recovery from the volume loss. In the later phases of the pandemic to September 2021, the volume and the revenue exceeded the loss.

This case study helped to identify key factors leading to successful resilience during the pandemic, i.e., flexibility and speed at which a company can adapt and overcome obstacles. Also, business safety can be ensured with a Business Continuity Plan guiding the company towards well-being, diversified market within the logistics companies, advanced IT systems, and appropriate leadership decisions and strategies.

\section{THEMATIC ANALYSIS}

This research section aimed to identify characteristics, the resemblance and dissimilarity between cases to find the case study's theme. For this purpose, crosscase analysis and thematic analysis were used. The results of the theme were based on key processes of the resilience cycle. The five key action stages (Scharte et al., 2014) consist of preparation, prevention, protection, response, and recovery.

The first stage for the five key processes of the resilience cycle starts with preparation; at this stage, firms begin to be aware of the pandemic and prepare for the potential situation to be faced shortly. A Business Continuity Plan or specific actions taken to cope with the pandemic are examples of the preparation stage. The second stage is the prevention of the virus from spreading to the inner circle of the company and reducing risk factors. The third key factor is protection. At this stage, companies have to ensure their safety from any negative impacts to come. The fourth stage is responding, i.e., companies taking action against the pandemic, such as implementing policies for working from home, social distancing and following the Business Continuity Plan to endure the workflow, health and safety of each individual. The last stage is recovery, at which companies had learned and finally adapted to coping with the situation of the pandemic and prepared for another possible pandemic in the future. 


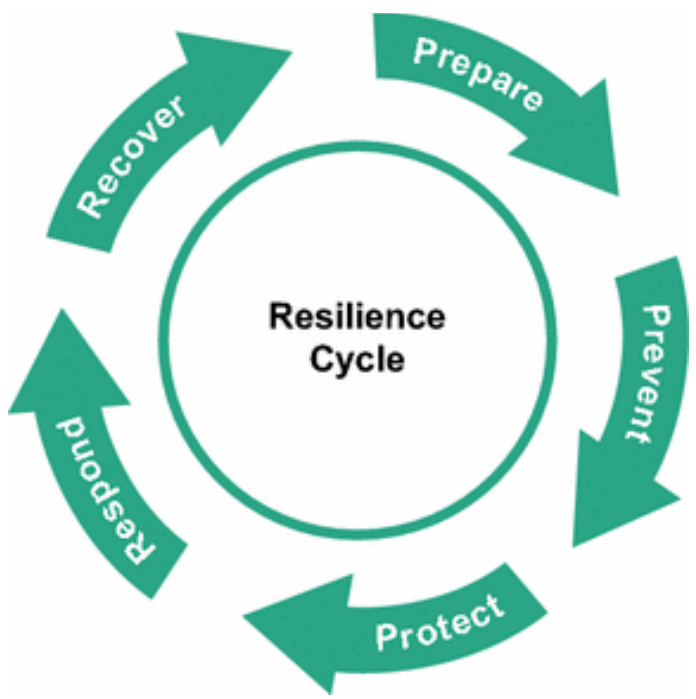

Fig. 1. Resilience Cycle

Source: (Scharte et al., 2014).

Tab. 2. Thematic Analysis for the processes of the resilience cycle

\begin{tabular}{|c|c|c|c|c|c|}
\hline \multicolumn{3}{|c|}{$\begin{array}{l}\text { DESCRIPTIVE OF THE } \\
\text { TRANSCRIPT }\end{array}$} & \multirow[b]{2}{*}{ CASE A } & \multirow[b]{2}{*}{ CASE B } & \multirow[b]{2}{*}{ CASE C } \\
\hline 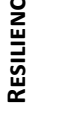 & 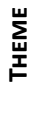 & ठั & & & \\
\hline 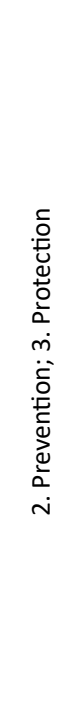 & 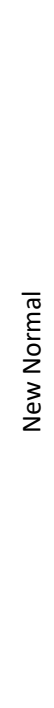 & 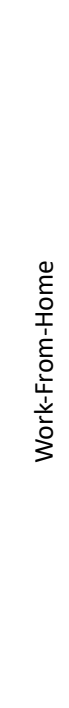 & $\begin{array}{l}\text { Company A had very few changes } \\
\text { because it was new and used a more } \\
\text { advanced system in the offices. The } \\
\text { work-from-home policy may have } \\
\text { created small challenges due to the } \\
\text { change in the working environment. } \\
\text { Respondents said that the work-life } \\
\text { balance might have been disturbed } \\
\text { due to working from home and the } \\
\text { lockdown. } \\
\text { Now, people have to learn to live } \\
\text { their lives under the "new normal" } \\
\text { conditions and adapt to change. }\end{array}$ & $\begin{array}{l}\text { Company B implemented a policy for } \\
\text { having half of their office staff work- } \\
\text { ing from home and rotating every } \\
\text { two weeks as a safety precaution } \\
\text { ensuring social distancing. } \\
\text { Business meetings were conducted } \\
\text { from home via Zoom and Google } \\
\text { Meet. } \\
\text { Staff members had to adapt their } \\
\text { homes to become their workspace } \\
\text { following the criteria given by the } \\
\text { company. } \\
\text { As the company is local and a } \\
\text { traditional type of workplace, hav- } \\
\text { ing to do the work from department } \\
\text { to department manually, it posed a } \\
\text { challenge. }\end{array}$ & $\begin{array}{l}\text { Company C ensured the } \\
\text { health and safety of their staff } \\
\text { by implementing the policy } \\
\text { for working from home. } \\
\text { Company C implemented } \\
\text { its own Business Continu- } \\
\text { ity Plan to maintain the } \\
\text { workflow. Based on the BCP, } \\
\text { employees were provided } \\
\text { with work laptops with a VPN } \\
\text { to the database. Company } \\
\text { C used WebEx to conduct } \\
\text { international meetings and } \\
\text { Zoom and Google Meet for } \\
\text { regular local meetings with } \\
\text { office staff. Telecommunica- } \\
\text { tion solutions were also used } \\
\text { to recruit new staff and for } \\
\text { online learning. }\end{array}$ \\
\hline 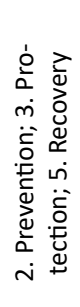 & 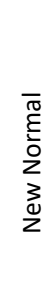 & 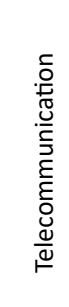 & $\begin{array}{l}\text { WebEx, Zoom, Google Meet, and } \\
\text { other means of telecommunica- } \\
\text { tion were used more regularly for } \\
\text { conducting the business. Before the } \\
\text { COVID-19 pandemic, new customers } \\
\text { were contacted and signed physi- } \\
\text { cally, but under the circumstances, } \\
\text { business meetings were conducted } \\
\text { online. }\end{array}$ & $\begin{array}{l}\text { The company continued working } \\
\text { traditionally; the adaption and adop- } \\
\text { tion of more telecommunication } \\
\text { solutions was a struggle. }\end{array}$ & $\begin{array}{l}\text { The company rented a private } \\
\text { VPN server to work within its } \\
\text { system based on the recom- } \\
\text { mendation from the Business } \\
\text { Continuity Plan. International } \\
\text { business was conducted } \\
\text { through telecommunications. }\end{array}$ \\
\hline
\end{tabular}




\begin{tabular}{|c|c|c|c|c|c|}
\hline 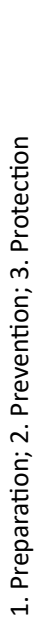 & $\begin{array}{l}\bar{\pi} \\
\stackrel{0}{\xi} \\
0 \\
2 \\
3 \\
0 \\
2\end{array}$ & 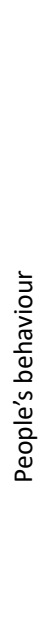 & $\begin{array}{l}\text { As a result of the lockdown, cus- } \\
\text { tomers became more interested in } \\
\text { e-commerce for online shopping, } \\
\text { creating a vast demand. }\end{array}$ & $\begin{array}{l}\text { People tend to buy things, and since } \\
\text { no money could be spent on trips, } \\
\text { vacations or shopping, the focus } \\
\text { fell on e-commerce. The COVID-19 } \\
\text { pandemic causes the fear of the } \\
\text { virus spreading to loved ones, so } \\
\text { people feel they have to self-isolate } \\
\text { and spend money online. }\end{array}$ & $\begin{array}{l}\text { The lockdown encouraged } \\
\text { customers to spend their } \\
\text { money on goods and services } \\
\text { from abroad, leading to } \\
\text { a huge advantage to the } \\
\text { logistics industry. }\end{array}$ \\
\hline 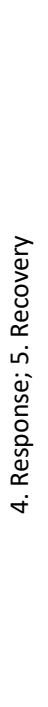 & 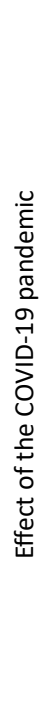 & 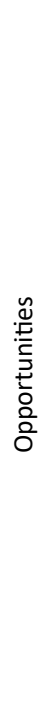 & $\begin{array}{l}\text { For a small business, the situation } \\
\text { took an unexpected turn and cre- } \\
\text { ated an opportunity that otherwise } \\
\text { might not have ever emerged, i.e., } \\
\text { new customers signing contracts } \\
\text { for services. Moreover, due to the } \\
\text { lockdown, e-commerce skyrocketed, } \\
\text { resulting in increased revenue. For } \\
\text { case A, the positive impact from the } \\
\text { COVID-19 pandemic was so high } \\
\text { that they could overlook the adverse } \\
\text { effect. } \\
\text { The company signed contracts be- } \\
\text { fore the COVID-19 pandemic for es- } \\
\text { sential goods and products, i.e., food } \\
\text { and pharmaceutical equipment; } \\
\text { these products played a key role in } \\
\text { the success of the company. }\end{array}$ & $\begin{array}{l}\text { A growing number of customers was } \\
\text { searching for logistics companies for } \\
\text { import and export once the capac- } \\
\text { ity of other logistics companies was } \\
\text { exceeded or the prices were too } \\
\text { high. Stocks for logistics companies } \\
\text { rapidly increased due to the high } \\
\text { service demand. }\end{array}$ & $\begin{array}{l}\text { The large company was ready } \\
\text { for significant events as it } \\
\text { had made advance plans for } \\
\text { dealing with the pandemic } \\
\text { as it already had experienced } \\
\text { many events, such as natural } \\
\text { disasters (volcano eruption, } \\
\text { floods etc.). This created an } \\
\text { advantage over other industry } \\
\text { players. The demand for logis- } \\
\text { tics was high, giving the com- } \\
\text { pany and the overall logistics } \\
\text { industry a high increase in } \\
\text { revenue (doubling its annual } \\
\text { revenue). } \\
\text { The large size and competitive } \\
\text { power in the industry pro- } \\
\text { vided the company with an } \\
\text { enormous advantage over } \\
\text { other players. }\end{array}$ \\
\hline 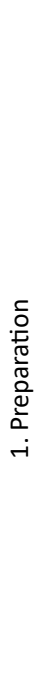 & 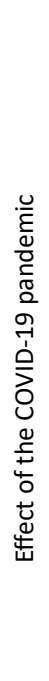 & 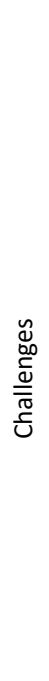 & $\begin{array}{l}\text { Companies in other industries, such } \\
\text { as clothing, had to lay off staff or } \\
\text { shut down due to the negative im- } \\
\text { pact of the pandemic. People were } \\
\text { unable to get out of their homes } \\
\text { and live their regular lives, shopping } \\
\text { and going on trips. Some companies } \\
\text { within the logistics industry could } \\
\text { not handle the negative impact } \\
\text { within the first phase of the pan- } \\
\text { demic and were forced to shut down } \\
\text { or stay on hold. } \\
\text { Initially, conducting the business and } \\
\text { adapting to the changes working } \\
\text { from home was a bit of a challenge. } \\
\text { However, once the company learned } \\
\text { to live under the "new normal" } \\
\text { conditions, the workflow increased } \\
\text { productivity. }\end{array}$ & $\begin{array}{l}\text { The adaptation to working from } \\
\text { home was difficult for the company } \\
\text { as it was more traditional in terms of } \\
\text { working style. Cancellation of orders } \\
\text { and production was a challenge } \\
\text { due to the pandemic; the company } \\
\text { suppliers had their difficulties and } \\
\text { caused delays or order cancellations. } \\
\text { Regular contractors expected orders } \\
\text { to be dropped. Another issue was a } \\
\text { more prolonged bottleneck within } \\
\text { the delivery process. Difficulties with } \\
\text { bookings and space for customers } \\
\text { could have led to the loss of custom- } \\
\text { ers and a decrease in volume. }\end{array}$ & $\begin{array}{l}\text { Working from home was } \\
\text { implemented for staff mem- } \\
\text { bers on-site and off-site, } \\
\text { causing some delays in the } \\
\text { delivery process in terms } \\
\text { of a bottleneck. Customers } \\
\text { cancelled orders to save their } \\
\text { businesses. As a total supply } \\
\text { chain solution provider, the } \\
\text { company had to look in detail } \\
\text { into every business process } \\
\text { for logistics. One issue was } \\
\text { the weight imbalance for } \\
\text { cargo due to no passengers } \\
\text { on aircrafts. Due to labour } \\
\text { and cargo shortage, the vol- } \\
\text { ume decreased by } 35 \% \text {. }\end{array}$ \\
\hline
\end{tabular}




\begin{tabular}{|c|c|c|c|c|c|}
\hline 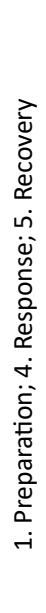 & 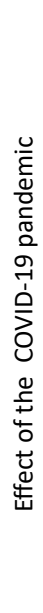 & 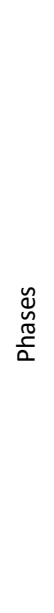 & $\begin{array}{l}\text { During phase } 1 \text { of the COVID-19 } \\
\text { pandemic in Thailand, several com- } \\
\text { plications emerged in the adjust- } \\
\text { ment and adaptation to the new } \\
\text { way of living. The panic in other } \\
\text { industries resulted in a decrease } \\
\text { in volume and revenue. However, } \\
\text { in the later phases ( } 2 \text { and 3), after } \\
\text { the adjustment, the effect became } \\
\text { positive due to the sudden lack of } \\
\text { equipment and space shortage. The } \\
\text { demand surged, causing a rise in } \\
\text { revenue. } \\
\text { During phase } 4 \text {, there were several } \\
\text { complications with bookings and the } \\
\text { capacity for customers as the market } \\
\text { is very competitive. }\end{array}$ & $\begin{array}{l}\text { The company found it difficult to } \\
\text { adjust during the first two phases. } \\
\text { However, once the policies were } \\
\text { fully adapted and adopted and plans } \\
\text { were adjusted to the pandemic, the } \\
\text { company started slowly recovering } \\
\text { from the loss accumulated in the } \\
\text { previous phases. }\end{array}$ & $\begin{array}{l}\text { As the company had a Busi- } \\
\text { ness Continuity Plan set } \\
\text { beforehand, it could continue } \\
\text { working with slight difficul- } \\
\text { ties by adapting the policies. } \\
\text { Once the company was fully } \\
\text { adjusted, the stocks and the } \\
\text { revenue escalated rapidly. The } \\
\text { company had the competitive } \\
\text { power to set the prices for } \\
\text { the customers as the demand } \\
\text { grew due to the sudden } \\
\text { service shortage. }\end{array}$ \\
\hline 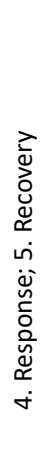 & 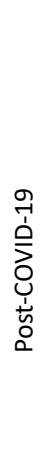 & 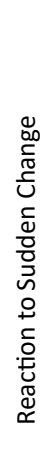 & $\begin{array}{l}\text { Shipping lines expected a massive } \\
\text { crisis from the pandemic, causing a } \\
\text { panic and pulling large vessels out } \\
\text { for saving the capacity and the cost } \\
\text { of holding the vessels; however, } \\
\text { the prediction made by the ship- } \\
\text { ping lines was wrong. The demand } \\
\text { surged from the pandemic, causing } \\
\text { a shortage in equipment, labour, and } \\
\text { shipping capacity. No one had ex- } \\
\text { pected a rapid increase in demand. } \\
\text { Investors worldwide became inter- } \\
\text { ested in the logistics industries and } \\
\text { bought stocks. }\end{array}$ & $\begin{array}{l}\text { People feared the virus, and no one } \\
\text { wanted to spread it to their loved } \\
\text { ones. There was a sudden labour } \\
\text { shortage, which caused a huge } \\
\text { disruption. } \\
\text { People stayed home and spent most } \\
\text { of their money on e-commerce } \\
\text { which positively affected the logis- } \\
\text { tics companies. }\end{array}$ & $\begin{array}{l}\text { For the first time in over } 30 \\
\text { years of the logistics industry, } \\
\text { aircrafts only transported } \\
\text { cargo without any passengers. }\end{array}$ \\
\hline 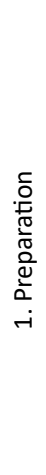 & 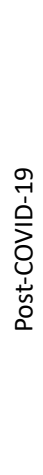 & $\sum_{\substack{\vdots \\
n}}^{\infty}$ & $\begin{array}{l}\text { Some other logistics companies had } \\
\text { to pause their activities or even shut } \\
\text { down at the start of the pandemic. } \\
\text { One factor for the shutdown could } \\
\text { have been the lack of need for the } \\
\text { transported goods during the crisis, } \\
\text { leading to a tremendous loss. Luck- } \\
\text { ily for company A, it transported } \\
\text { necessary goods, such as food and } \\
\text { pharmaceutical equipment. The } \\
\text { respondent observed that the food } \\
\text { industry always survives during } \\
\text { crises as it is an essential part of our } \\
\text { lives. }\end{array}$ & $\begin{array}{l}\text { Social distancing, working from } \\
\text { home, telecommunication solutions, } \\
\text { and disinfection are necessary for } \\
\text { the safety of staff and maintenance } \\
\text { of the company's workflow. They are } \\
\text { the top priority. } \\
\text { The company believes it may recov- } \\
\text { er faster than the loss was acquired } \\
\text { in the first stages of the pandemic. }\end{array}$ & $\begin{array}{l}\text { The company had experience } \\
\text { with other serious events, } \\
\text { such as natural disasters, so } \\
\text { it knew how to cope with } \\
\text { situations like the COVID-19 } \\
\text { pandemic. The company spe- } \\
\text { cialises in electrical products, } \\
\text { which are essential for every- } \\
\text { one, especially at times like } \\
\text { these, such as laptops or PCs } \\
\text { for working from home. }\end{array}$ \\
\hline 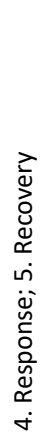 & 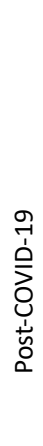 & 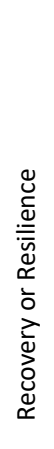 & $\begin{array}{l}\text { Once required adaptations were } \\
\text { made, logistics companies started } \\
\text { slowly recovering from losses ex- } \\
\text { periences in the first phases of the } \\
\text { COVID-19 pandemic in Thailand. }\end{array}$ & $\begin{array}{l}\text { The company has overcome the } \\
\text { challenges faced in the first two } \\
\text { phases and is slowly recovering. }\end{array}$ & $\begin{array}{c}\text { As there were many losses } \\
\text { in the volume, the company } \\
\text { gained more revenue from } \\
\text { the pandemic. }\end{array}$ \\
\hline
\end{tabular}




\section{DISCUSSION AND CROSS-CASE ANALYSIS}

All three cases have shown the resilience plans of preparation, prevention, protection, response, and recovery. All three companies had a Business
Continuity Plan in advance to prevent the spread of the virus within the company and protected themselves by following plans and policies regarding their safety.

Furthermore, all three cases showed signs of making a quick recovery. Some cases may differ slightly and lag on the recovery due to the pandemic.

Tab. 3. Cross-case comparison

\begin{tabular}{|c|c|c|c|}
\hline CASE ANALYSIS FACTOR & CASE A & CASE B & CASE C \\
\hline $\begin{array}{c}\text { Interviewee's } \\
\text { management position }\end{array}$ & Managing Director & $\begin{array}{c}\text { Business Development Execu- } \\
\text { tive }\end{array}$ & Managing Director \\
\hline Level of education & Bachelor & Masters & Highschool \\
\hline $\begin{array}{l}\text { Years in the experience of } \\
\text { logistic industry }\end{array}$ & 20 & 10 & 36 \\
\hline Covered region & Global & $\begin{array}{c}\text { Global, but focuses mainly in } \\
\text { South-East Asia }\end{array}$ & Global \\
\hline Office headquarter location & $\begin{array}{c}\text { Ekamai } \\
\text { Centre of Bangkok }\end{array}$ & $\begin{array}{c}\text { Bangna } \\
\text { Suburb of Bangkok }\end{array}$ & $\begin{array}{c}\text { Lat Krabang } \\
\text { Suburb of Bangkok }\end{array}$ \\
\hline Communication channel & $\begin{array}{l}\text { Telecommunication video } \\
\text { conference }\end{array}$ & $\begin{array}{l}\text { Telecommunication video } \\
\text { conference }\end{array}$ & $\begin{array}{l}\text { Telecommunication video } \\
\text { conference }\end{array}$ \\
\hline Effect from Phase 1 & Negative & Negative & Negative \\
\hline Effect from Phase 2 & Positive & Negative & Positive \\
\hline Effect from Phase 3 & Positive & Positive & Positive \\
\hline Effect from Phase 4 & Negative & Positive & Positive \\
\hline Overall Effect of COVID-19 & Positive & Negative & Positive \\
\hline Opportunities & $\begin{array}{l}\text { E-commerce, more customers, } \\
\text { increased demand etc. }\end{array}$ & $\begin{array}{l}\text { E-commerce, more customers, } \\
\text { increased demand; increased } \\
\text { price charged, growth in e- } \\
\text { commerce shipments from } \\
\text { online platforms etc. }\end{array}$ & $\begin{array}{l}\text { Increased e-commerce, in- } \\
\text { creased revenue by } 200-400 \\
\% \text { due to a sudden shortage, } \\
\text { air-charter, customers using } \\
\text { different freight, increased } \\
\text { willingness-to-pay, competitive } \\
\text { power etc. }\end{array}$ \\
\hline Challenges & $\begin{array}{l}\text { Working from home, cancella- } \\
\text { tion of orders and production, } \\
\text { regular contractors expecting } \\
\text { orders dropped etc. }\end{array}$ & $\begin{array}{l}\text { Working from home, cancella- } \\
\text { tion of orders and production, } \\
\text { regular contractors expecting } \\
\text { orders dropped, a lengthier } \\
\text { bottleneck within the delivery } \\
\text { process, harder to book and } \\
\text { get space for customers, which } \\
\text { might lead to loss of a cus- } \\
\text { tomer etc. }\end{array}$ & $\begin{array}{c}\text { Working from home, some } \\
\text { cancellation of orders, weight- } \\
\text { balance for air cargo, volume } \\
\text { decreased by } 35 \% \text {, shortage } \\
\text { in labour \& cargo, a lengthier } \\
\text { bottleneck within the delivery } \\
\text { process etc. }\end{array}$ \\
\hline $\begin{array}{c}\text { Actions are taken in response } \\
\text { to the COVID-19 }\end{array}$ & $\begin{array}{l}\text { Working from home, using } \\
\text { more telecommunications etc. }\end{array}$ & $\begin{array}{l}\text { Working from home, rotating } \\
\text { employees in each depart- } \\
\text { ment, sending original billing } \\
\text { documents by postal service } \\
\text { and less visits by bike mes- } \\
\text { sengers, allocation of service } \\
\text { counter to segregate external } \\
\text { visitors to a specific larger } \\
\text { area to reduce crowding and } \\
\text { promote digitalisation of work } \\
\text { (telecommunication) etc. }\end{array}$ & $\begin{array}{l}\text { Rotating divisions for work } \\
\text { from home, promoting greater } \\
\text { digitalisation, using telecom- } \\
\text { munications as a means for } \\
\text { conducting businesses and } \\
\text { ensuring the business work- } \\
\text { flow, providing laptops with } \\
\text { VPN access to the company's } \\
\text { system. }\end{array}$ \\
\hline
\end{tabular}




\begin{tabular}{|c|c|c|c|}
\hline CASE ANALYSIS FACTOR & CASE A & CASE B & CASE C \\
\hline Risk Management & $\begin{array}{l}\text { Social distancing, working from } \\
\text { home, wearing masks, using } \\
\text { alcohol gel/spray regularly etc. }\end{array}$ & $\begin{array}{l}50 / 50 \text { working from home } \\
\text { policy with rotation and } \\
\text { limited customers visitation, } \\
\text { refraining as much as possible } \\
\text { from outside visitors. Provided } \\
\text { transportation services for em- } \\
\text { ployees from home to office } \\
\text { (and vice versa). Company B } \\
\text { relocated their counter service } \\
\text { to the warehouse for releasing } \\
\text { B/L and D/O. Staff had to wear } \\
\text { masks while working and use } \\
\text { alcohol gel, with a temperature } \\
\text { check-up policy. Transferring } \\
\text { employees with a temperature } \\
\text { higher than } 37.5^{\circ} \mathrm{C} \text { to the hos- } \\
\text { pital. Postponing all business } \\
\text { travel until further notice. Prior } \\
\text { agreement required from the } \\
\text { management before private } \\
\text { trips or annual leave; offices } \\
\text { regularly deep cleaned and } \\
\text { disinfected etc. }\end{array}$ & $\begin{array}{l}\text { Implementation of the Busi- } \\
\text { ness Continuity Plan (BCP), } \\
\text { working from home poli- } \\
\text { cies. The company provided } \\
\text { employees with laptops and } \\
\text { separated them into Teams } \\
\text { A and B for weekly shifts (on- } \\
\text { site staff) to prevent crowding } \\
\text { (ensure social distancing); VPN } \\
\text { (rented the VPN server for } \\
\text { conducting work from home); } \\
\text { wearing masks, social distanc- } \\
\text { ing, alcohol disinfectant, wash- } \\
\text { ing hands etc. }\end{array}$ \\
\hline Future Plans & Plans for Expansion & $\begin{array}{l}\text { Expansion branch (a new of- } \\
\text { fice located at Suvarnabhumi } \\
\text { Airport) }\end{array}$ & TBA \\
\hline
\end{tabular}

The resilience of companies was impacted during the four phases of the pandemic. During the first phases, the outcome of the pandemic for the logistics industry was negative. Sudden changes were made to adapt to the situation to ensure adaptation and survivability. The pandemic is difficult for companies with low flexibility and having to implement such changes as an online platform to be used for working from home or generate plans to be used during the pandemic. The readiness and flexibility of a company result in adaptiveness and a positive impact.

Within the first phase of the COVID-19 pandemic, companies in the logistics industry faced a loss of customers, shortage of labour and equipment, cancellation of orders and production, and a decrease in the volume of import and export, resulting in decreased total revenue. The overall theme for the first phase was a negative impact.

In the second phase of the COVID-19 pandemic, two-thirds of studied companies demonstrated quick resilience and experienced a positive impact. The positive impacts resulted from companies being flexible. Business Continuity Plans helped to protect the companies from pandemic outcomes. Also, e-commerce was used more frequently by customers as a result of the lockdown, which had a positive impact on the companies. Due to the high demand for logistics, revenue began to multiply.
In the third and fourth phases of the pandemic, the logistics companies recovered and experienced positive effects with businesses improving.

Based on the thematic analysis and cross-case comparison, the following factors were identified as necessary for the logistics firms to be resilient during the pandemic.

The flexibility in the workplace adaptation, so work could continue during the lockdown or implemented special procedures for safety. A company with great flexibility will have a more positive impact than a company with low flexibility. Creating or adopting a Business Continuity Plan played a massive role in business resilience during the pandemic.

A Business Continuity Plan is a programme of means for the prevention and protection of the business resulting in its resilience. To better use or improve the Business Continuity Plan, the company needs to assess it through regular reviews and identify threats clearly to prepare good solutions. The plan must be followed up with an analysis of the pandemic effects for certain areas of the business, making sure that the plan is accessible and tested regularly. As the case study demonstrated, companies that implement a Business Continuity Plan recover faster than companies that have no plan or lag behind with its drafting.

A positive impact can be achieved by diversifying products provided to the customer, e.g., essential prod- 


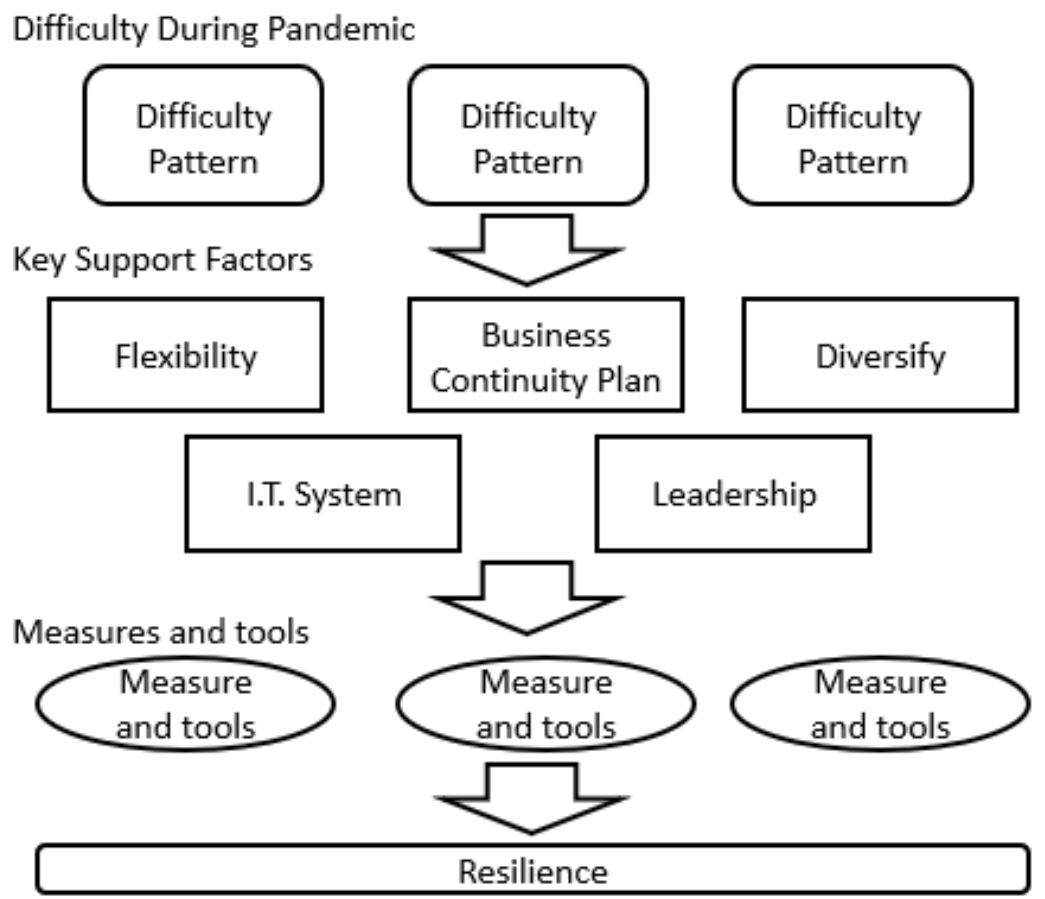

Fig. 2. Identification of key supporting factors for resilience of logistics firms

ucts (food), electrical equipment (for online learning and working from home), pharmaceutical equipment etc. By diversifying the market, companies can average out the risk of negative impacts with the positive impacts to improve growth or further develop the business.

IT systems play a critical role in resilience for coping with the pandemic. Advanced systems tend to have a more positive impact than less up-to-date systems. Adjusting the company's workflow with the help of IT systems ensures continuous business operation.

Moreover, the last key success factor for the company's resilience is leadership knowing how to strategically manage the company in times of crisis. Leadership is among the most important aspects of the company's stability during the pandemic. Supervision helps the company advance through struggles following a strategic plan for operational and financial business management.

\section{CONCLUSION}

COVID-19 has been a massive disruption in all industries, causing many companies to shut down. However, in the midst of the negativity, some positive effects were discovered. The logistics industry was among the few that survived and improved due to the pandemic. Even though some challenges were faced initially, companies that managed to survive the first phase of the pandemic will see a positive effect.

This research paper looked at the impact of the COVID-19 pandemic on the logistics industry and its resilience. The thematic analysis research was based on a semi-structured interview of three companies in the Thai logistic industry and their activities from the beginning of March 2020 to September 2021, covering four phases of the COVID-19 pandemic in Thailand. The semi-structured interview was recorded for transcription to be used for further analysis. Thematic analysis was the selected deductive approach for distinguishing the codes and generating the themes for this research, using resilience key factors as guidance for the interviewed questions.

The research identified key factors that resulted in the resilience of logistics firms during the pandemic: flexibility, Business Continuity Plan, diversified market, IT systems, and leadership. These factors should be confirmed in a further study by empirical evidence, such as Analytic Hierarchy Process (AHP) and multiple regression.

Other companies in logistics industries are advised to implement a Business Continuity Plan. It helps the company to be prepared for crises. Companies that have a Business Continuity Plan tend to move towards a positive effect and show strong recovery from the pandemic. Additionally, the plan helps to prepare for the later stage of the post-pandemic. 


\section{ACKNOWLEDGEMENTS}

The authors would like to thank the participants from the three companies for allowing to conduct the case study for the research. This research is fully supported by the Center of Excellence in Logistics and Supply Chain Systems Engineering and Technology (COE LogEn), Sirindhorn International Institute of Technology Thammasat University.

The publication of the article for 11th International Conference on Engineering, Project, and Production Management - EPPM2021 was financed in the framework of the contract no. DNK/SN/465770/2020 by the Ministry of Science and Higher Education within the "Excellent Science" programme.

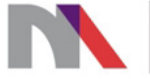

Ministry of Science and Higher Education

Republic of Poland

\section{LITERATURE}

Al-Ayed, S. I. (2019). The impact of strategic human resource management on organizational resilience: an empirical study on hospitals. Business: Theory and Practice, 20, 179-186. doi: 10.3846/btp.2019.17

Amankwah-Amoah, J. (2021). COVID-19 pandemic and innovation activities in the global airline industry: A review. Environment International, 156, 106719.

Asano, T., \& Nagayama, A. (2021). Analysis of workload required for removal of drifting pumice after a volcanic disaster as an aspect of a port business continuity plan: A case study of Kagoshima Port, Japan. Journal of Disaster Risk Reduction, 64, 102511.

Aviv-Sharon, E., \& Aharoni, A. (2020). Generalized logistic growth modeling of the COVID-19 pandemic in Asia. Infectious Disease Modelling, 5, 502-509. doi: 10.1016/j.idm.2020.07.003

Barman, A., Das, R., \& Kanti De, P. (2021). Impact of COVID-19 in food supply chain: Disruptions and recovery strategy. Current Research in Behavioral Sciences, 2,100017

Ivanov, D. (2020). Predicting the impacts of epidemic outbreaks on global supply chains: A simulation-based analysis on the coronavirus outbreak (COVID-19/ SARS-CoV-2) case. Transportation Research Part E: Logistics and Transportation Review, 136, 101922.

Li, Z., Zhou, Q., Chen, M., \& Liu, Q. (2021). The impact of COVID-19 on industry-related characteristics and risk contagion. Finance Research Letters, 39, 101931.

Malavika, B., Marimuthu, S., Joy, M., Nadaraj, A., Asirvatham, E. S., \& Jeyaseelan, L. (2021). Forecasting COVID-19 epidemic in India and high incidence states using SIR and logistic growth models. Clinical Epidemiology and Global Health, 9, 26-33. doi: 10.1016/j.cegh.2020.06.006
Maneenop, S., \& Kotcharin, S. (2020). The impacts of COVID-19 on the global airline industry: An event study approach. Journal of Air Transport Management, 89, 101920.

Scharte, B., Hiller, D., Lerismann, T., \& Thoma, K. (2014). Introduction. In K. Thoma (Ed.), Resilien-Tech "Resilience by Design": a strategy for the technology issues of the future (pp. 9-17). München, Germany: Herbert Utz Verlag.

Sharma, G. D., Thomas, A., \& Paul, J. (2021). Reviving tourism industry post-COVID-19: A resilience-based framework. Tourism Management Perspectives, 37, 100786.

Spieske, A., \& Birkel, H. (2021). Improving supply chain resilience through industry 4.0: A systematic literature review under the impressions of the COVID-19 pandemic. Computers \& Industrial Engineering, 158, 107452.

Thoma, K., Scharte, B., Hiller, D., \& Leismann, T. (2016). Resilience Engineering as Part of Security Research: Definitions, Concepts and Science Approaches. European Journal for Security Research, 1, 3-19. doi: 10.1007/s41125-016-0002-4

Wang, H., Lo, Y., Liu, Y., Qing, F., Zhou, Y., Chen, Y., \& Fang, D. (2021). Study on the Influencing factors of urban economic resilience in post epidemic Era A case study of Kunming City. Journal of Urban Management, 10, 255-264.

Wang, Y.-C., \& Chen, T. (2021). A Bi-objective AHP-MINLP-GA approach for Flexible Alternative Supplier Selection amid the COVID-19 pandemic. Soft Computing Letters, 3, 100016.

Wen, W., Yang, S., Zhou, P., \& Gao, S. Z. (2021). Impacts of COVID-19 on the electric vehicle industry: Evidence from China. Renewable and Sustainable Energy Reviews, 144, 111024. 